\title{
Research Paper \\ Modeling the Structural Relationships of Conflicts between Parents and Students with Aggression: The Mediating Role of Moral Disengagement
}

\author{
Zohre Mohammad Eini ${ }^{1}$, Jamal Sadeghi ${ }^{2}$, Fariborz Dortaj ${ }^{3}$, Alireza Homayoni ${ }^{4}$
}

1. Ph.D. Candidate in Educational Psychology, Babol Branch, Islamic Azad University, Babol, Iran

2. Assistant Professor, Department of Psychology, Babol Branch, Islamic Azad University, Babol, Iran

3. Professor, Department of Educational Psychology, Faculty of Psychology and Educational Sciences, Allameh Tabataba'i

University, Tehran, Iran

4. Assistant Professor, Department of Psychology, Bandar Gaz Branch, Islamic Azad University, Bandar Gaz, Iran

Citation: Mohammad Eini Z, Sadeghi J, Dortaj E, Homayoni A. Modeling the structural relationships of conflicts between parents and students with aggression: the mediating role of moral disengagement. Quarterly Journal of Child Mental Health. 2020; 7(2): 41-54.

\section{http://dx.doi.org/10.29252/jemh.7.2.5}

\section{A R T I C L E I N F O}

\begin{tabular}{l}
\hline Keywords: \\
Parent-adolescent \\
conflict, \\
moral disengagement, \\
aggression
\end{tabular}

Received: 23 Feb 2020

Accepted: 30 May 2020

Available: 20 Sep 2020

\section{A B S T R A C T}

Background and Purpose: Aggression is a social damage which is increasing in the society. In addition, aggression is one of the most important issues of childhood and adolescence which is related to parent-child relationships and family conflicts. Therefore, present study aimed to modeling the structural relationships of conflicts between the parents and adolescents with aggression through the moderating role of moral disengagement in female students.

Method: This was a study with descriptive-correlational design and structural equations. The study population included all the female students studying at the secondary schools of Qom in the academic year of 2019-2020. A sample of 607 students was selected by multi-stage cluster sampling to participate in this research. The participants answered Parent-Child Relationship Scale (Fine, Moreland, \& Schwebel, 1983), Moral Disengagement Scale (Caprara et al., 2006) and Aggression Questionnaire (Buss \& Perry, 1992). To analyze the data, structural equations modeling with AMOS was used.

Results: Results showed that effect of adolescent-parent conflict on moral disengagement $(\mathrm{P}<0.01$, $\beta=0.67)$ and aggression $(\mathrm{P}<0.01, \beta=0.47)$ was positive and significant. The effect of moral disengagement on aggression $(\mathrm{P}<0.01, \beta=0.26)$ was positive and significant. Moral disengagement had a positive and significant mediating role in the relationship between parent-adolescent conflict and adolescent aggression $(\mathrm{P}<0.01, \beta=0.17)$.

Conclusion: Based on the results of the present research, it can be concluded that the parentadolescent conflict leads to the increase of moral disengagement and aggression in female students. Also, moral disengagement increases the relationship between parent-adolescent conflict and aggression.

\footnotetext{
* Corresponding author: Jamal Sadeghi, Professor, Assistant Professor, Department of Psychology, Babol Branch, Islamic Azad University, Babol, Iran.

E-mail addresses: Jamalsadeghi48@yahoo.com
} 


\section{مدل يابى روابط ساختارى تعارضات والدين و دانش آموزان با يرخاشكرى: نقش ميانجى بـ تفاوتى اخلاقى}

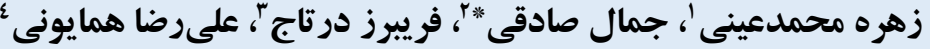

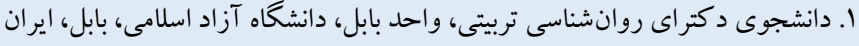

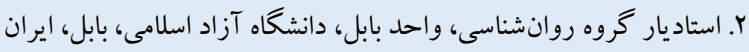

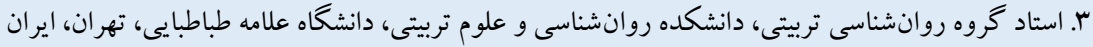

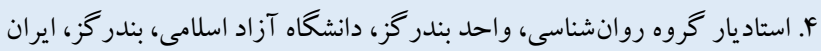

\section{جكيده}

زمينه و هدف: بِرخاشخرى يكى از آسيبهاى اجتماعى است كه در جامعه در حال افزايش است. به همين جهت، برخاشخرى يك مسئله

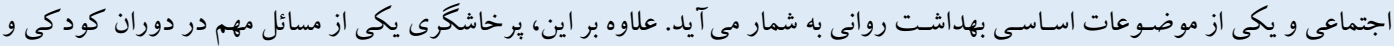

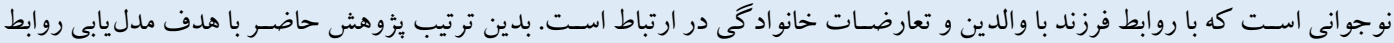

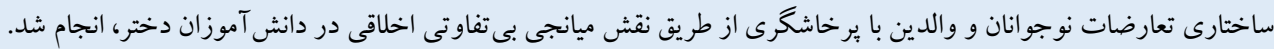
روش: نوع ئووهش حاضر، توصيفى و از نوع همبستخى و معادلات ساختارى بود. جامعه آمارى اين مطالعه شامل تمامى دانش آموزان دختر

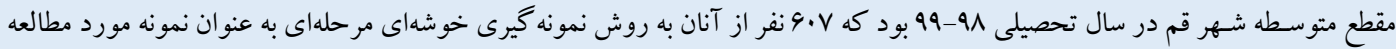

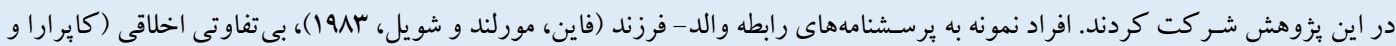

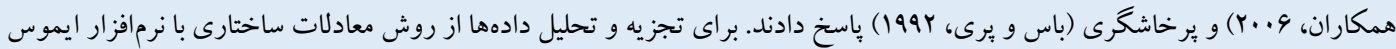
استفاده شد.

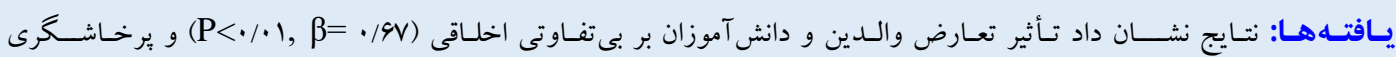

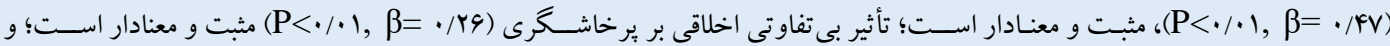

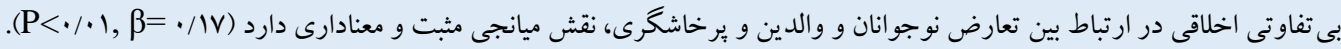

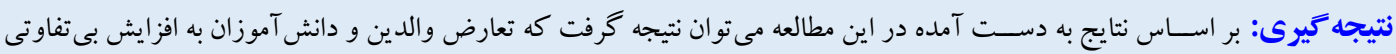

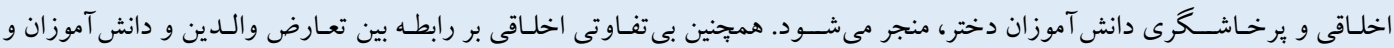
إِرخاشكرى آنان، مى افزايد.
مشخصات مقاله

كليدوازهها:

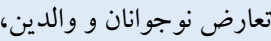

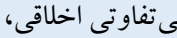

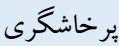

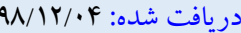

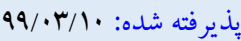

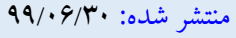

* نويسنده مسئول: جمال صادقى، استاديار گروه روانشناسى، واحد بابل، دانشكاه آزاد اسلامى، بابل، ايران. راياناه: 


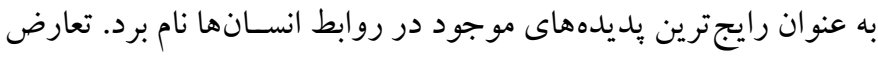

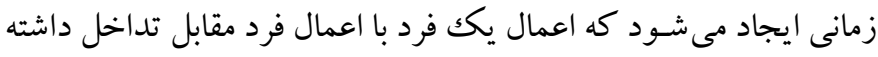

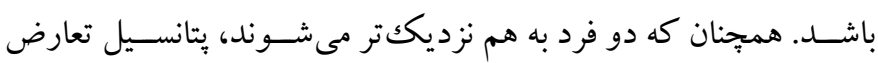
افزايش مى يابد؛ در حقيقت وقتى تعاملات بين افراد بيشتر شده و فعاليتها

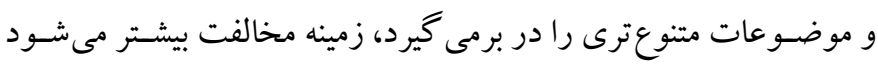
(V) مى كند. تعارضـات سـازنده، موضسوعاتى هسـتند كه در آنها صسحبت در

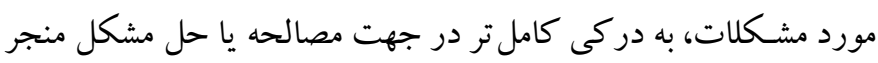
مى شـود و همجِنين موجب كاهش هيجانات منفى شــده، احترام و اعتماد

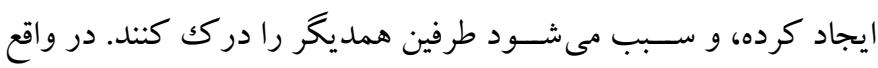

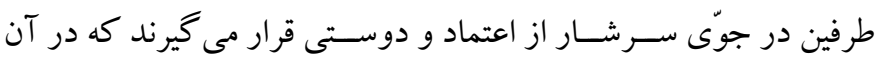

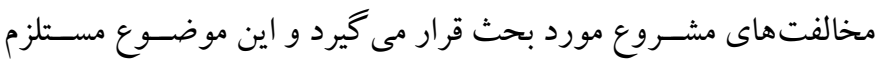

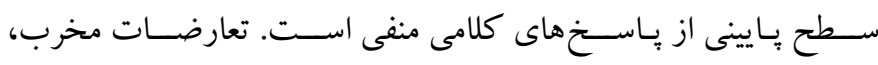

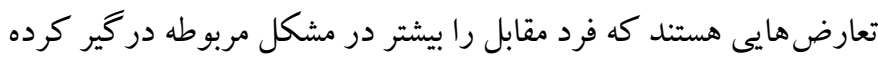

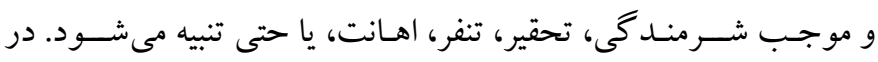

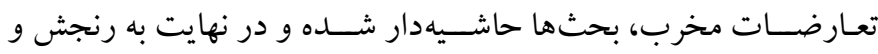
خصومت نسبت به شخص مخاطب، كاهش اعتماد، اطمينان، و همكارى به به به

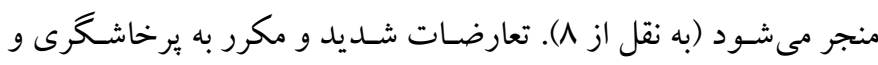

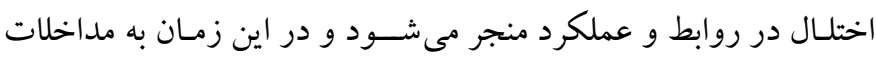

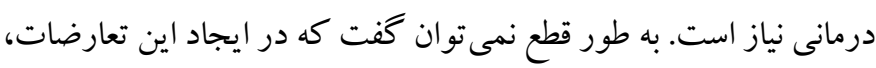

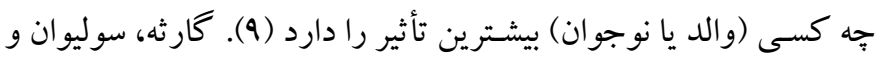

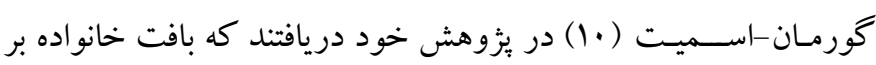
خشـونت نوجوانان تأثير دارد. لابلا و ماسـتن (11) دريافتند كه رفتارهاى دوردي

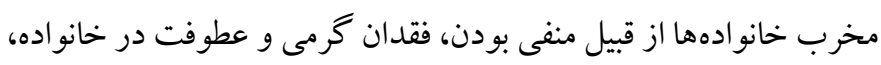

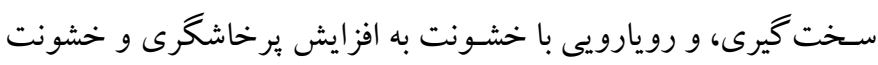

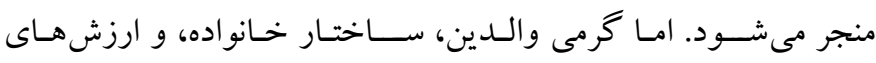

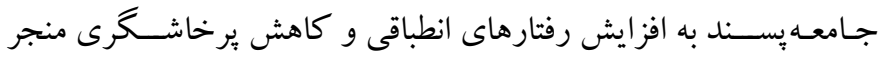

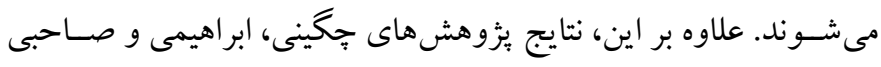

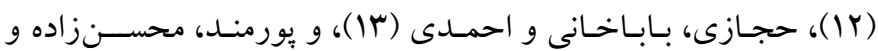

4. Constructive

5. Destructive
مقلدمه

يرخاشــرى ' يكى از آسـيبـهاى اجتماعى اسـت كه در جامعه رو به

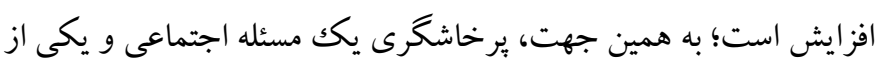
موضوعات اساسى بهداشت روانى افراد جامعه به شمار مى آيد (1). علاوه

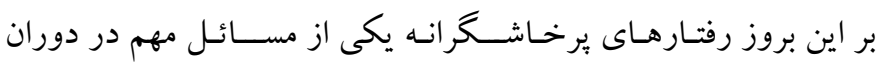

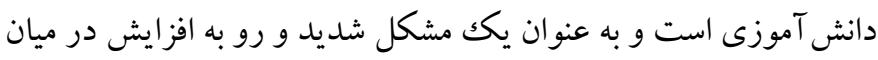

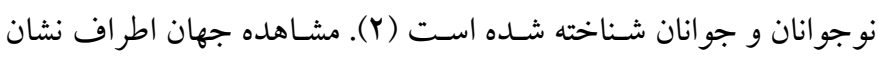

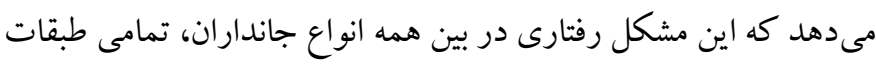

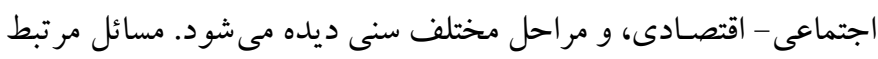

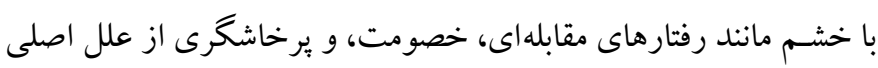

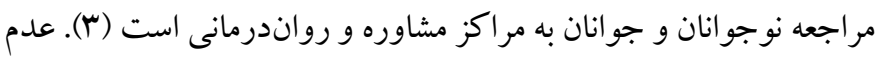

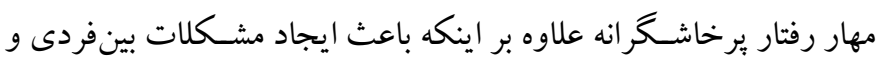

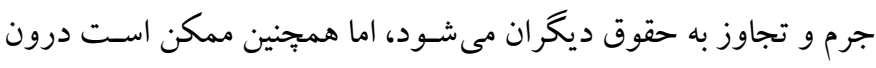

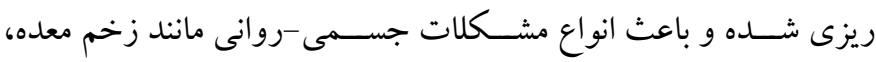

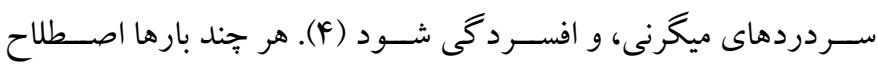

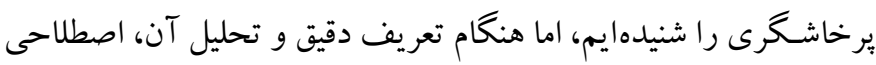

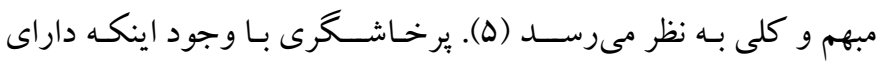

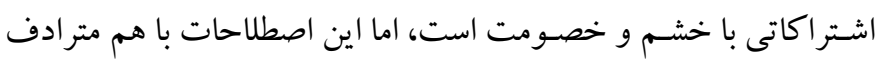

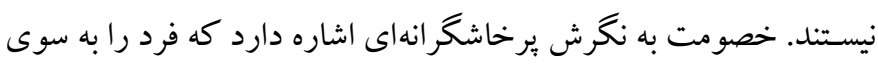

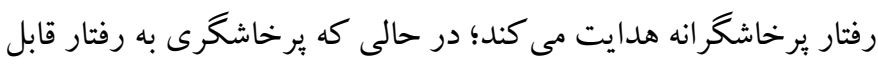

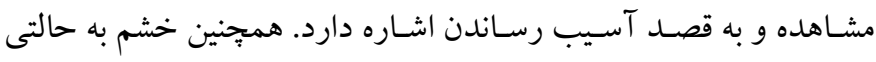

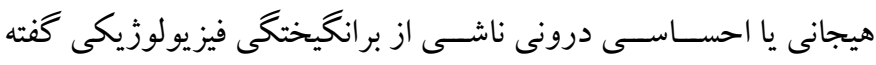

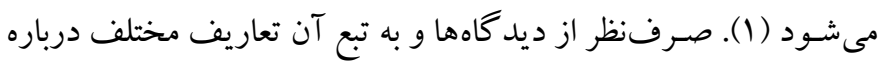

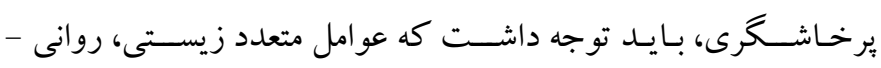

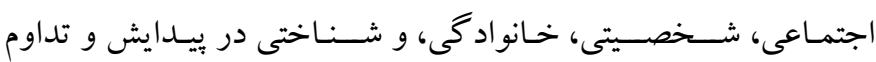
ير خاشخرى، نقش دارند.

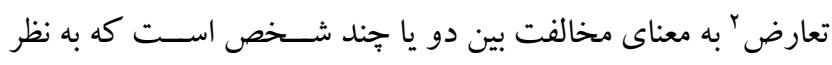

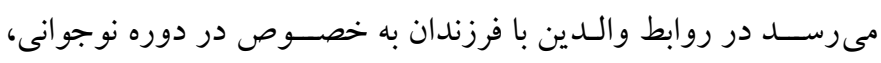

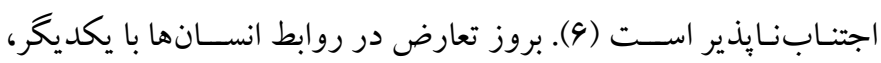

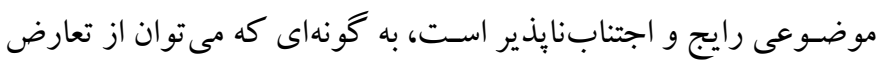

1. Aggression

2. Conflict

3. Rice 
قربانى ها كماهميت جلوه مىدهند) را شـامل مىشـود. دسته جهارم شامل

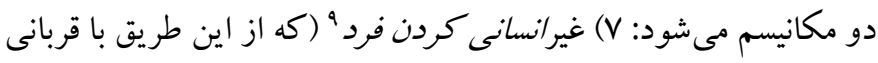

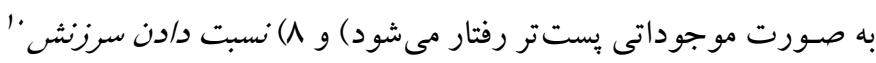

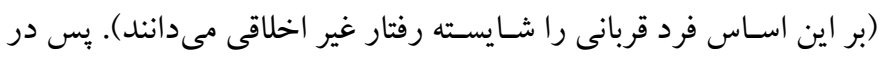

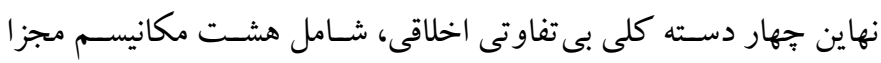

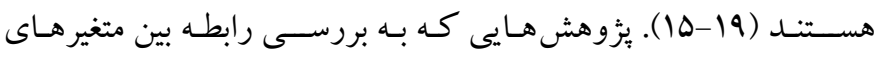

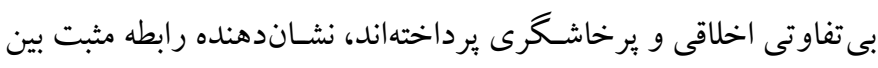

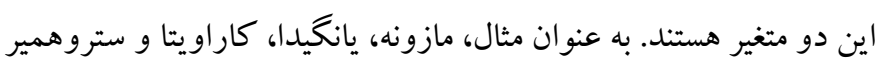

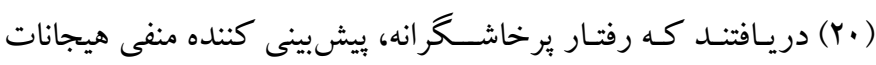

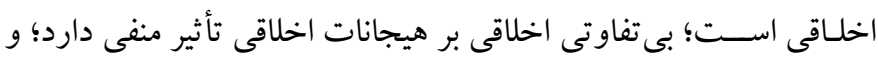

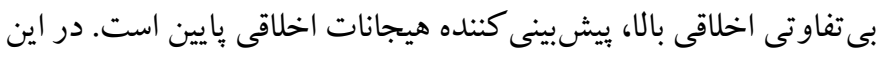

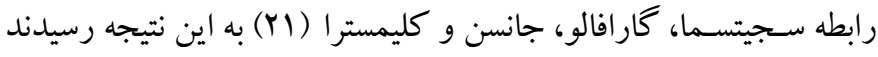

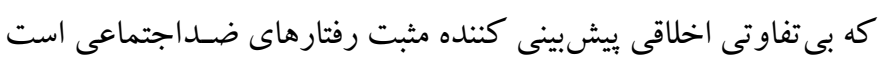

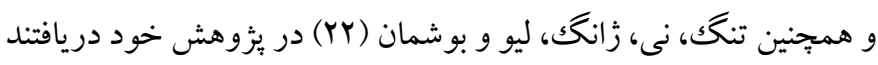

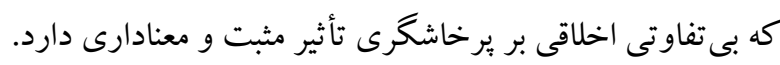

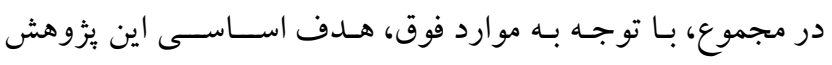

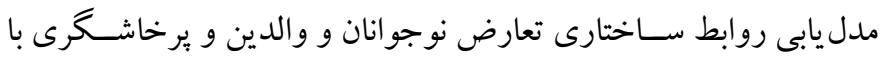

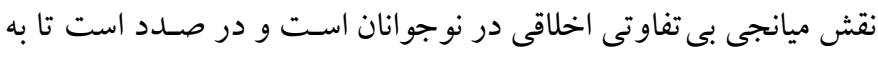

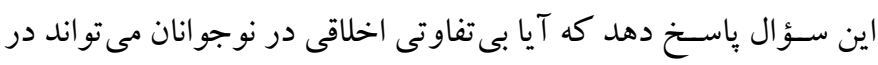

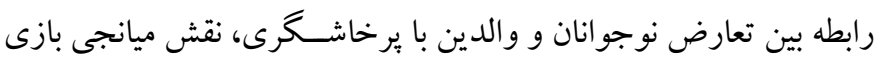

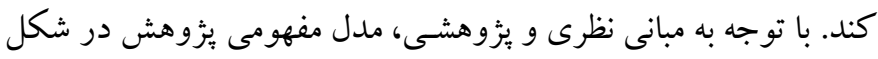

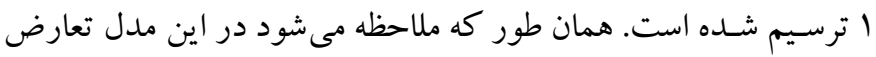
نوجو انـان و والـدين بــه عنو ان متغير مســتقل، بـى تفاوتى اخلاقى به عنوان

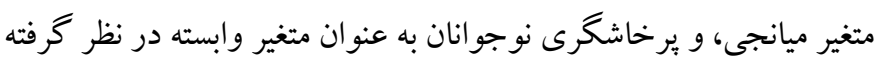
شدهاند. بنابراين فرضيه هاى بزوهش حاضر به صورت زر است:

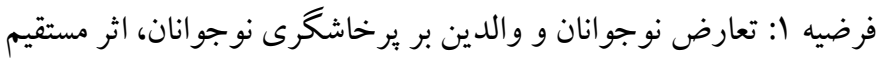
دارد.

فرضيه ؟: بى تفاوتى اخلاقى بر برخاشكرى نوجوانان، اثر مستقيم دارد.

6. Displacement of responsibility

7. Diffusion of responsibility

8. Distorting consequences

9. Dehumanization

10. Attribution of blame
قائدنياى (F) نيز بيانكر تأثير تعارض نوجوانان و والدين بر برخاشـحرى

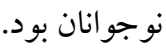

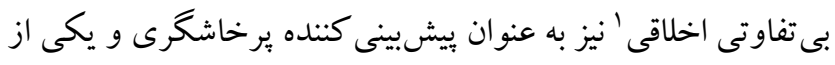

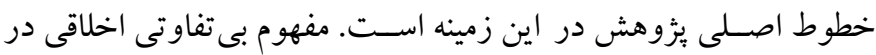

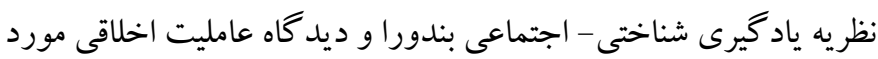

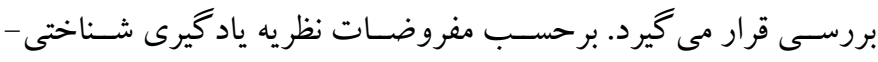

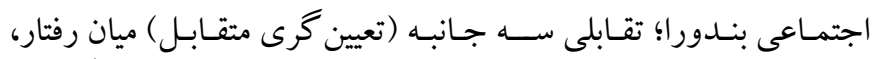
متغيرهـاى محيطى و عوامـل مرتبط بـا فرد وجود دارد. بر اين مبنـا رفتـار

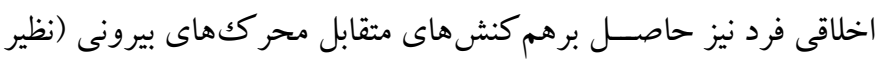

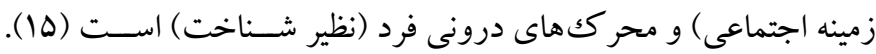

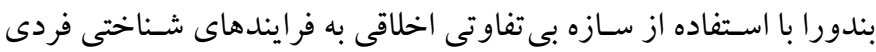

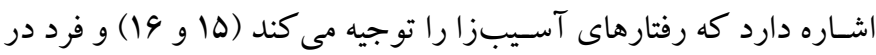

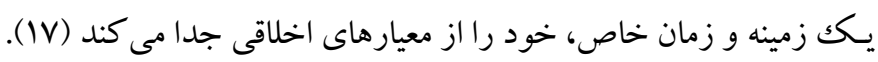

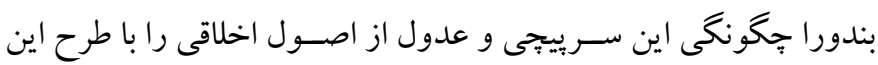

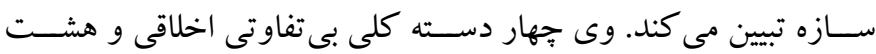

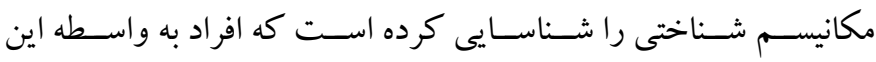

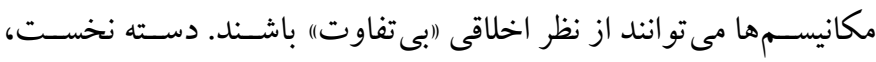

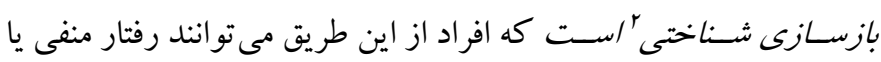
غير اخلاقى را مثبت تر بييند كه خود شامل سه مكانيسم مىشود: (1) توجيه

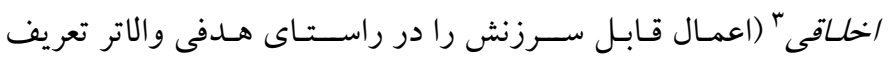

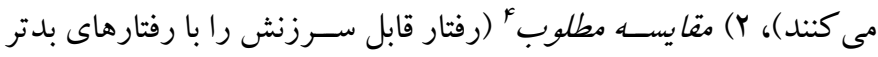
مقايسـه مى كنند)، ؟) حســن تعبيره ( قابل قبول تر كردن رفتار از طريق

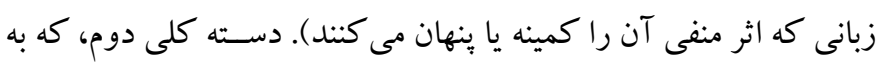
حداقل رسـاندن نقش عامليتى فرد مربوط مى شـود كه شامل دو مكانيسم

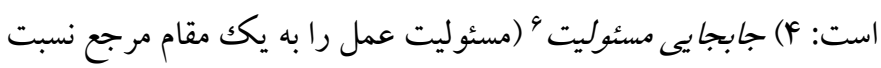

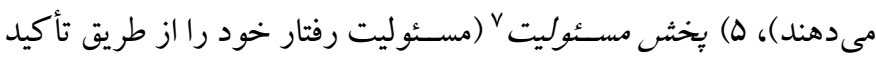

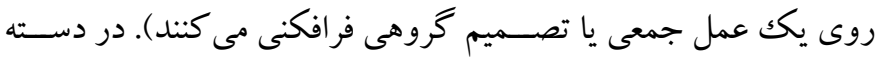

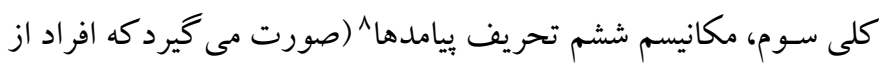

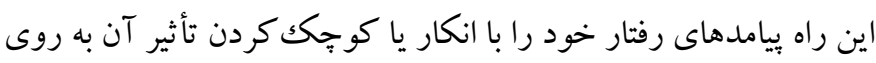

1. Moral disengagement

2. Cognitive restructuring

3. Moral justification

4. Advantageous comparison

5. Euphemistic language 
فرضـيه بّ: تعارض نوجوانان و والدين با ميانجيخرى بى تفاوتى اخلاقى بر يرخاشخرى نوجو انان، اثر غير مستقيم دارد.

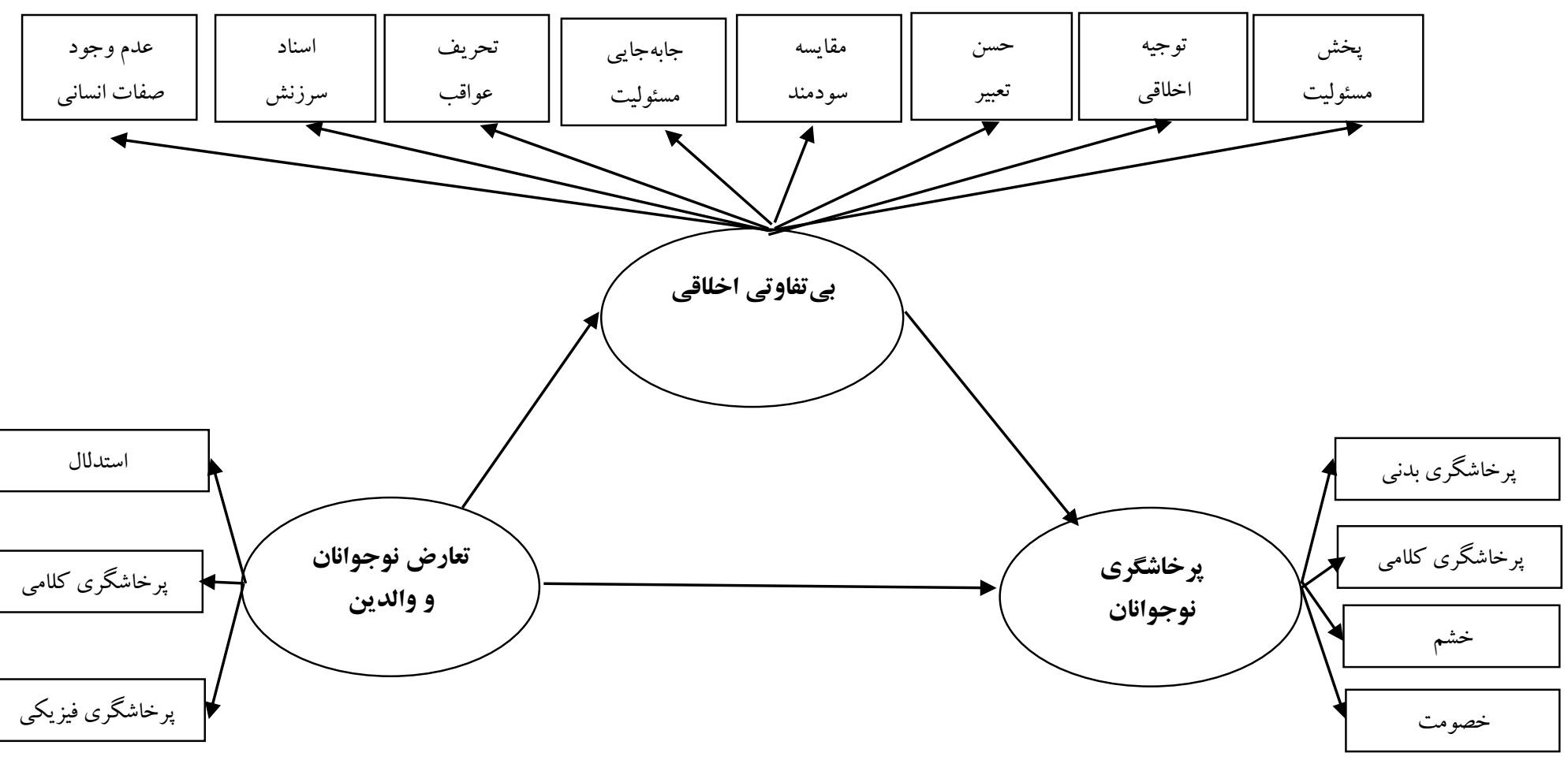

شكل ا: مدل مفهومى يخوهش

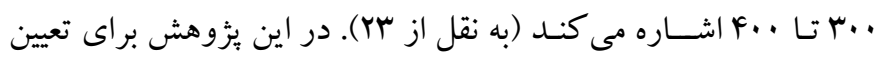
حجم نمونـه بـا توجـه بــه تعـداد متغيرهاى مشـــاهده شـــده (V IV متغير) و تخصـيص ضــريسب له براى هر متغير، و بـا احتســاب احتمــال وجود يرسـشـنامهاى ناقص، VY9 نفر به عنوان نمونه مورد نظر انتخاب شـدند. دانش آموزان بـه روش نمونسه كيرى خوشــهاى مرحلهاى در ســـه مرحله

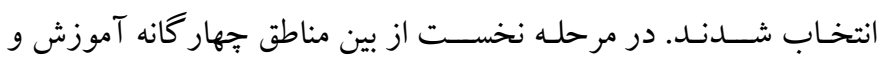
يرورش قم، Y منطقه به صـورت تصــادفى انتخاب شــدند. ســـس از هر منطقه، هل مدرسـه و از هر مدرسـه سـه كلاس به صسورت تصادفى انتخاب شدند و در نهايت تعداد وVYGنفر از دانش آموزان اين كلاسها يرسشنامهها را تكميل كردند كه يس از حذف يرسـشـنامههايى كه ناقص پياسـخ داده شــده بودند، G·V يرسـشـنامه مورد تحليل قرار گرفتند. معيارهاى ورود به بزوهش شامل رضايت آكاهانه براى شركت در بزوهش، جنسيت مؤنث، و تحصسيل در مقطع متوسـطه؛ و معيارهاى خروج از يزٔوهش شـامل عدم

3. MacCallum
1. Kline

2. Loehlin
روش الف) طرح هزوهش و شـر كت كنند كان: نوع اين مطالعه، توصسيفى و طرح يزوهش، همبستـى از نوع مدل معادلات سـاختارى اسـت؛ زيرا در اين ئزوهش، روابط بين متغير ها در قالب يك الكوى علّى مورد بررسـى قرار كرفته است. جامعه آمارى بثزوهش حاضر شامل تمامى دانش آموزان دختر مقطع متوسـطه در دامنه سـنى بين 19 تا 1 1 سـال شـهر قم در سـال تحصيلى 91 99 بودند. در زمينه بر آورد حجم نمونه بهينه براى مطالعات مربوط بـه مدل يابى معادلات ســاختارى، نظرات متفاوتى وجود دارد. از

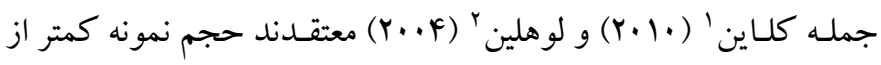

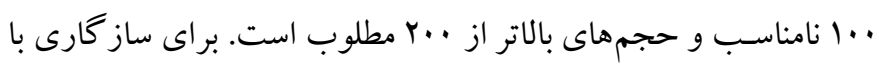

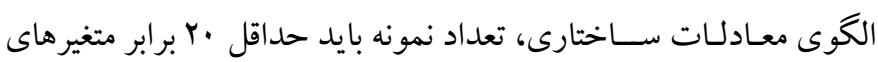

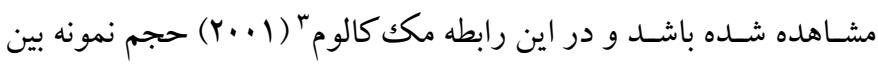

. Loehlin 
اكتشــافى مورد بررسـى قرار داد. روايى همزمـان با به كاركيرى مقياس

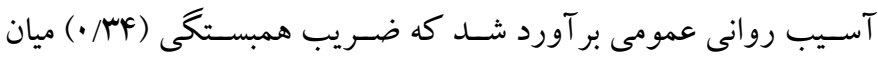

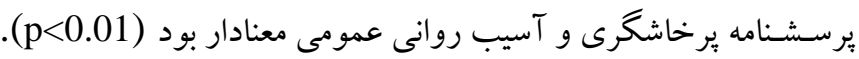
نتايج تحليل عو امل با اسـتفاده از روشهاى مؤلفه هاى اصسلى و خرخش واريمـاكس نشــان داد كه اين يرســــــنامه از جهار عامل خصــومت،

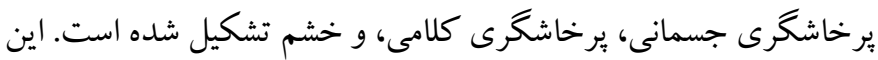
عوامل، بيشـتر از 4\$ درصــ واريانس كل را تبيين مى كنند. علاوه بر اين،

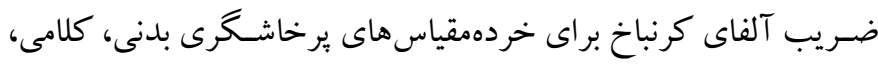

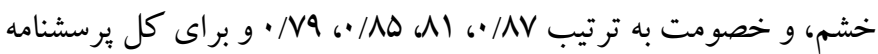

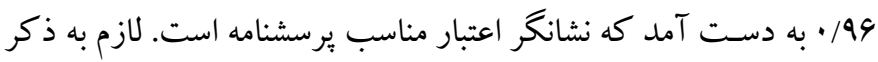
اسـت كه نتايج مربوط به شــاخص هاى برازش تحليل عاملى تأييدى در

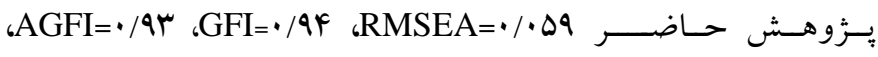
NFI=•/9V , CFI=•/9A

$$
\text { اين برسشنامه است. }
$$

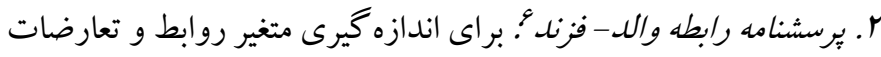

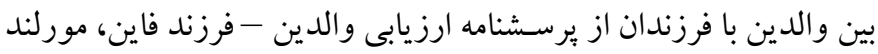

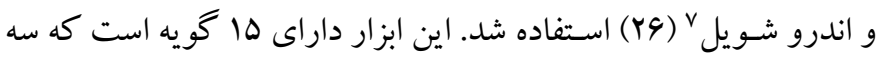

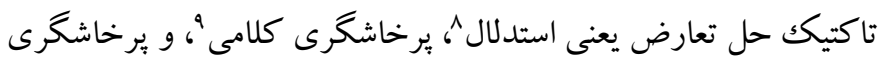

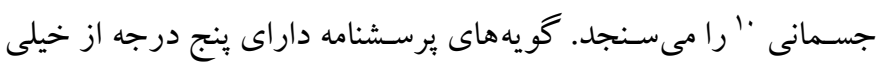

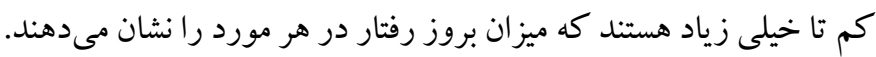

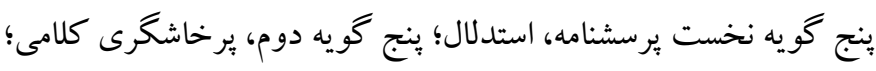

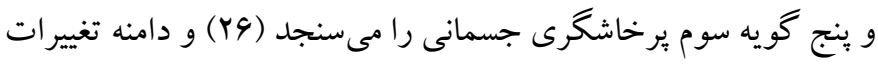

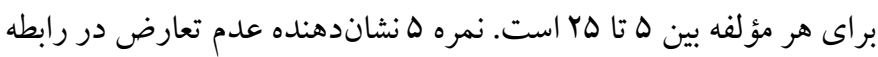

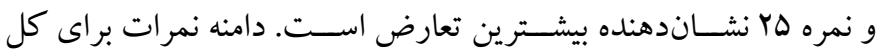

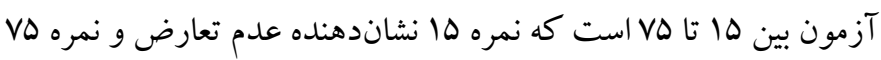
نشـاندهنده بيشـترين تعارض اسـت. اين مقياس توسـط فاين، مورلند و

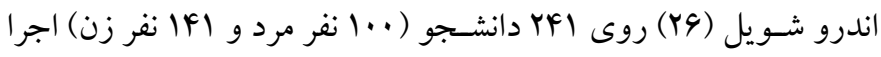

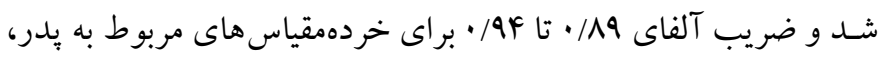

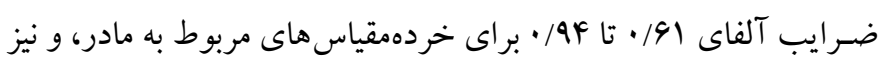

6. Parent-child relationship scale (PCRS)

7. Fine, Moreland \& Schwebel

8. Reasoning

9. Verbal aggression

10. Physical aggression
رضـايت و همكارى از سوى دانش آموز و وجود برسشنامههاى مخدوش

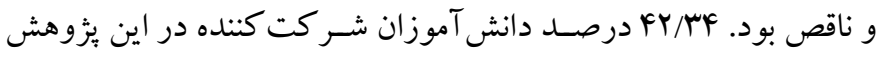

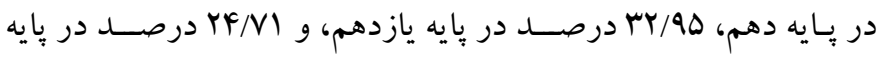
دوازدهم مشـغول به تحصـيل بودند. همجنين بيشـتر شـر كت كنند كان در يزوه هش داراى وضعيت اجتماعى اقتصادى متوسط بودند.

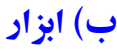

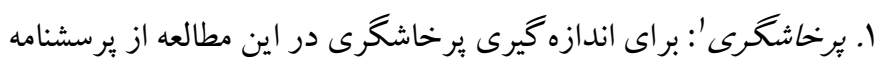

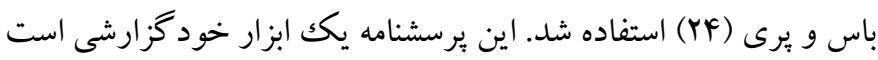

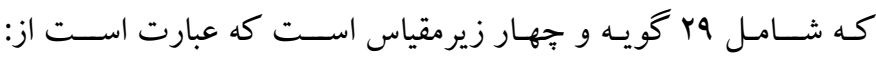

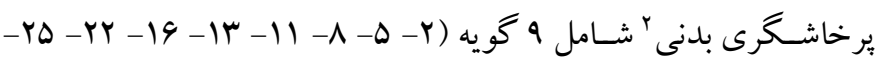

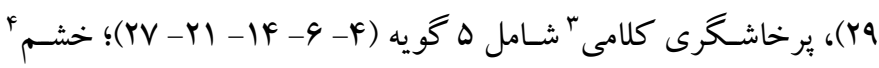
شـامل V Vويه (1كويه (rه درجه اى از كاملاً شبيه من است (ه)، تا حدودى شبيه من است (F) (ه)، نه

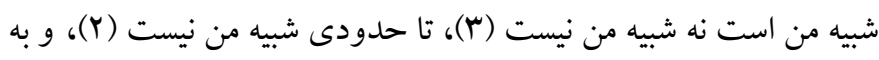

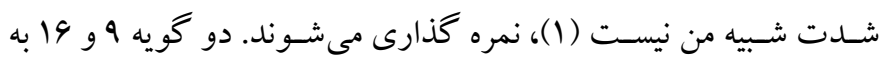

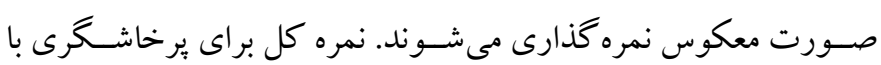

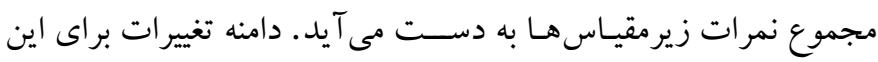

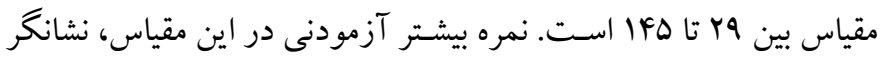
برخاشخرى بيشتر آزمودنى است و بالعكس.

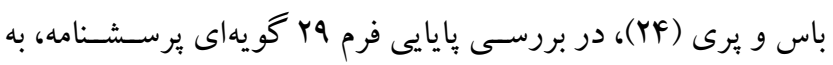

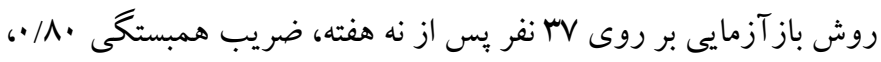

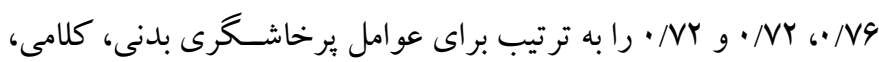

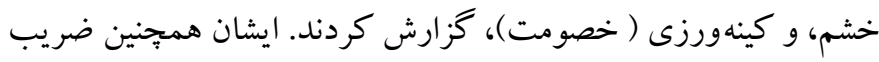

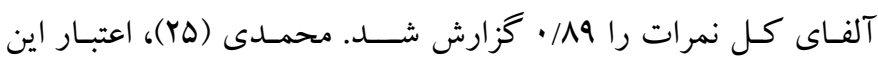

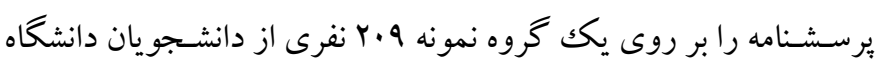
شسيراز، به سـه روش آلفاى كرونباخ، باز آزمايى، و تنصسيف مورد تحليل

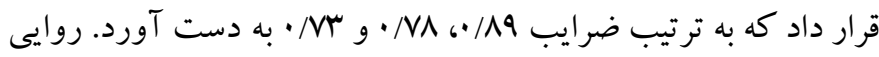

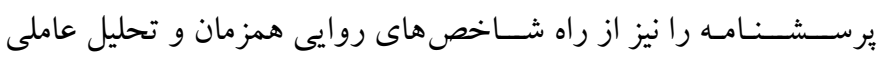

1 The aggression questionnaire- AQ

2. Physical aggression

3. Verbal aggression

4. Anger

5. Hostility 
براى خردهمقياسهاى تو جيه اخلاقى، حســن تعبير، مقايســه ســودمند، جابهجايى مسئوليت، بخخش مسئوليت، تحريف عو اقب، اسناد سرزنش، و

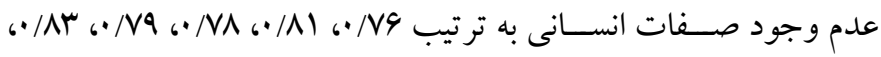

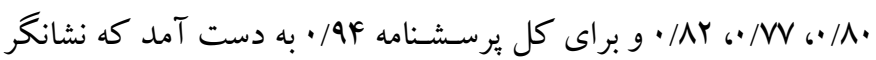
اعتبار مناسـب برسـشـنامه اسـت. در ئزوهش حاضـر شاخص هاى برازش

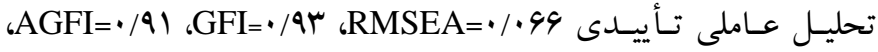
به دسـت آمد كه نشـانخر روايى مناســب اين $\mathrm{NFI=•/9 \Delta ,CFI=•/9V}$ يرسشنامه است. ج) روش اجرا: يس از دريـافت مجوزهاى للازم علمى، ادارى و اجرايى از سـازمان آموزش و برورش اسـتان قم (شـهر قم)، افراد نمونه به شـرح

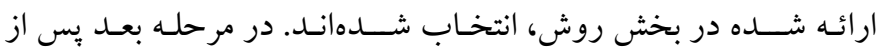
همـاهنخى بـا مدير ان و معلمان مدارس و توضــيح هدف هاى يزوهش و اطمينان از جلب رضـايت دانش آموزان، يرسشنامهاى بزّوهش اجرا شد. ملـاحظـات اخلـاقى از قبيل رضــايت آكاهانه دانش آموزان براى تكميل يرسـشـنامه، محر مانه ماندن و رازدارى مشـخصـات و اطلاعات شـخصى دانش آموزان، در اين مطالعه به طور كامل رعايت شــد. در نهايت جهت تجزيه و تحليل دادهها از ضريب همبستكى بيرسون و روش مدل معادلات ساختارى با نسخه FF نرمافزار SPSS و AMOS استفاده شد.

\section{يافتهها}

در جدول اشـاخص هاى توصسيفى متغيرهاى بثزوهش شــامل ميانخين،

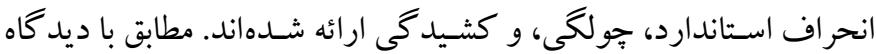

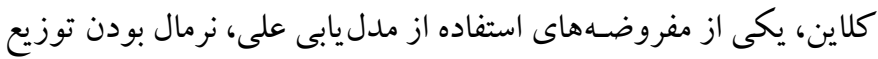

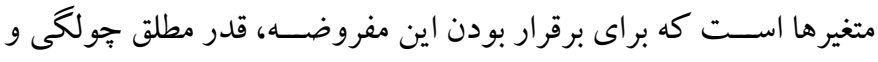

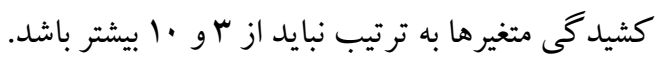

6. Diffusion of responsibility

7. Distorting consequences

8. Attribution of blame

9. Dehumanization
آلفـاى كلى 99/• به دســت آمد و حاكى از همســانى درونى بالاى اين مقياس است.

اين برسـشـنامه در ايران توسـط زابلى در سـال سمشا بر روى اجرا شـد كه اعتبار آن را براى كل آزمون FF/ • و براى خردهمقياسهاى

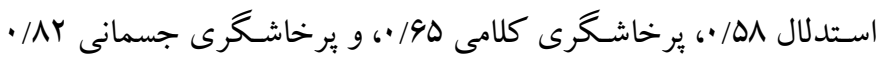
كزارش كردند (rV) كرونبـاخ براى خردهمقيـاسهـاى اســـــلـال، يرخـاشـــــ كلـامى، و

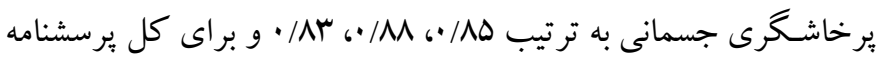

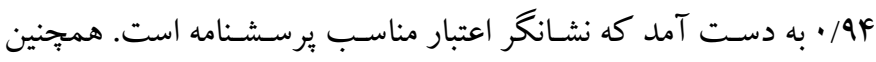

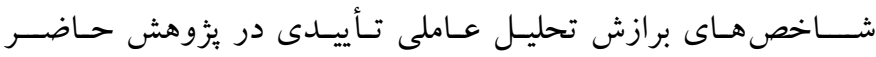
$\mathrm{NFI}=\cdot / 94, \mathrm{CFI}=\cdot / 9 \Lambda$, $\mathrm{GGFI}=\cdot / 9 \uparrow, \mathrm{GFI}=\cdot / 9 \uparrow, \mathrm{RMSEA}=\cdot / \cdot 9 \uparrow$ به دست آمده است كه نشانكر روايى مناسب اين برسشنامه است. ". بـىتغاوتى اخلاقى ': براى اندازه گيرى بى تفاوتى اخلاقى از برسـشــنامه

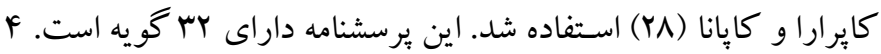
كويه توجيه اخلاقى ' (N)

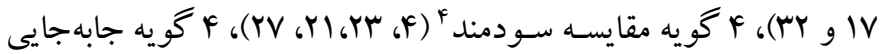

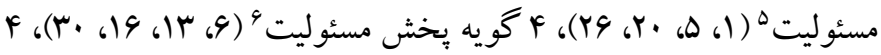

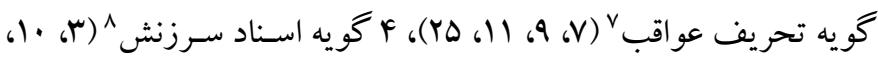

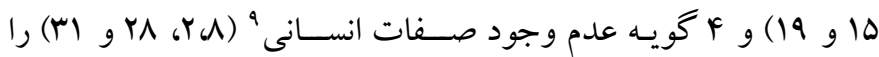
مى ســنجند. دامنه تغييرات براى اين مقياس بين rس تا .19 اسـت كه نمره بالاتر، نشـانه بى تفاوتى اخلاقى بيشتر مىباشد. ضريب اعتبار اين برسشنامه با استفاده از ضريب آلفاى كرونباخ در مطالعه كايراراو كايانا (YA) AF/. به دسـت آمد. آنها همجنين جهت بررسـى روايى برسـشــامه از تحليل عـاملى تـأييدى اســتفاده كردند كه شــاخصهاى برازش تحليل عاملى

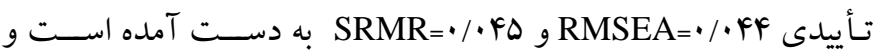
نشانگر روايى مناسب يرسشنامه بود. علاوه بر اين، ضريب آلفاى كرونباخ
1. Assessing moral disengagement

2. Moral justification

3. Euphemistic language

4. Advantageous comparison

5. Displacement of responsibility 
جدول ا: شاخصهاى توصيفى متغير هاى ثزووهش

\begin{tabular}{|c|c|c|c|c|}
\hline كشيدىى & جولكى & انحراف استاندارد & ميانكين & متغيرها \\
\hline - & ./Irr & IY/AF & KG/YY & تعارض نوجو انان و والدين \\
\hline$\cdot / 499$ & 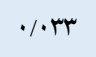 & rI/ro & $Q \Delta / F F$ & بى تفاوتى اخلاقى \\
\hline.$- / 490$ &.$/ \Lambda \Delta$ & $r r / 99$ & $\wedge \Delta / \vee q$ & يرخاشكرى نوجوانان \\
\hline
\end{tabular}

${ }^{* *} \mathrm{P}<\cdot / \cdot 1$

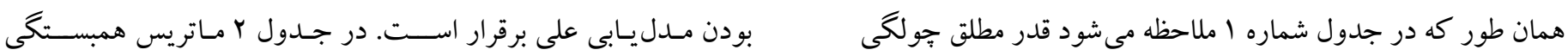

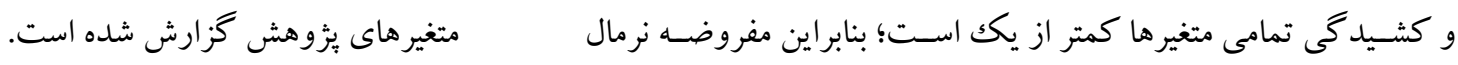

جدول r: ماتريس همبستغى متغيرهاى ثزوهش

\begin{tabular}{|c|c|c|c|}
\hline يرخاشكرى نوجوانان & بى تفاوتى اخلاقى & تعارض نوجوانان و والدين & متغيرها \\
\hline & & 1 & تعارض نوجو انان و والدين \\
\hline & 1 & $\cdot / 9 \cdot \cdots$ & بى تفاوتى اخلاقى \\
\hline 1 & $\cdot / \Delta r^{\text {糔 }}$ & $\cdot / \Delta V^{* * * *}$ & ير خاشگرى نوجوانان \\
\hline
\end{tabular}

${ }^{* *} \mathrm{P}<\cdot / \cdot 1$

(CFI) ) شـاخص برازش هنجار شـده (NFI) و شـاخص برازش هنجار

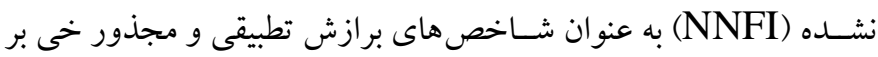

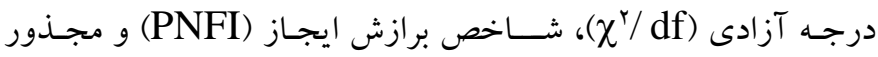

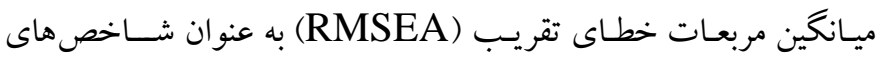
برازش مقتصد در نظر گرفته شدهاند.

\begin{tabular}{|c|c|c|c|}
\hline \multicolumn{4}{|c|}{ شاخصهاى برازش مطلق } \\
\hline SRMR & AGFI & GFI & شاخص \\
\hline .1 .49 & $\cdot / 9 F$ &.$/ 90$ & مقدار بدست آمده \\
\hline \multicolumn{4}{|c|}{ شاخصهاى برازش تطبيقى } \\
\hline NNFI & NFI & CFI & شاخص \\
\hline.$/ 99$ & $\cdot / 91$ &.$/ 99$ & مقدار بدست آمده \\
\hline \multicolumn{4}{|c|}{ شاخص هاى برازش تعديل يافته } \\
\hline RMSEA & PNFI & $\chi^{\Upsilon} / \mathrm{df}$ & شاخص \\
\hline.$/ . \Delta 4$ & $\cdot / \mathrm{VI}$ & r/M & مقدار بدست آمده \\
\hline كمتر از ^•• & بيشتر از .19. & كمتر از r & حد قابل يذيرش \\
\hline
\end{tabular}

همان طور كه در جدول Y مشاهده مى شود ضريب همبستگى تعارض

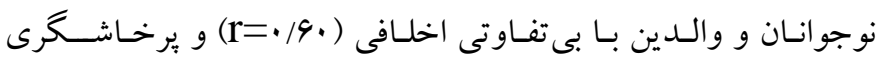

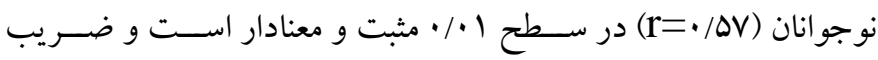

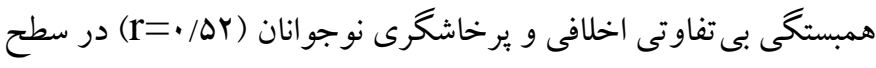
1 • • مثبت و معنادار است. جهــت آزمـون الكوى نظرى يزٔوهش و برازش آن بـا دادههـاى كرد آورى شـده از روش بيشينه احتمال استفاده شد. جهت استفاده از اين روش، للزم اسـت كه نرمال بودن جندمتغيره متغيرها بررسى شود. در اين

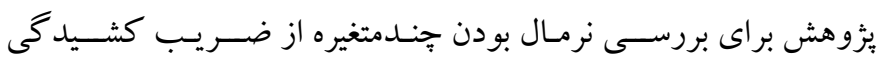

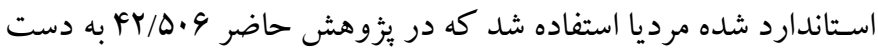
آمد كه كمتر از عدد هله اسـت و با استفاده از فرمول (p+2p(p) محاسبه شده است. مطابق با اين فرمول p مساوى است با تعداد متغيرهاى مشاهده شده كه در اين يزوهش ها است. در جدول ب مشـخصه هاى برازندگى الخوى معادلات ساختارى يعنى برازش مطلق، تطبيقى و تعديل يافته به تفكيك گزارش شده است. در اين

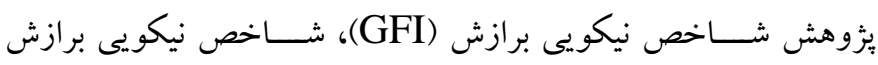
تعديل يافته (AGFI) و ريشـه ميانكين مربعات باقيمانده اسـتاندارد شـده به عنوان شـاخص هاى برازش مطلق، شاخص برازش تطبيقى (SRMR) 
مقادير استاندارد شــده روى هر كدام از مسـيرها درج شـده اسـت. همان

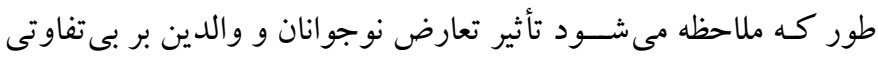

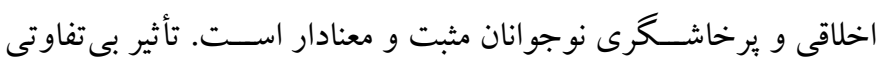
اخلاقى بر برخاشخرى نوجوانان مثبت و معنادار است.
در جدول سا، مقادير به دســت آمده در بزوهش حاضسر و حد قابل يذيرش هر يكك از شــاخص هاى برازش گز ارش شـــــاند. نتايج نشـــان

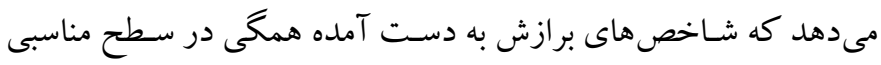
هستـند و دادههاى اين يزٔوهش با ساختار عاملى اين مدل، برازش مناسبى

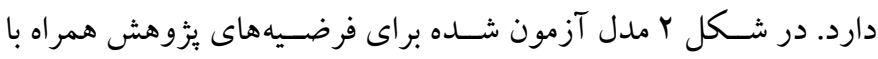

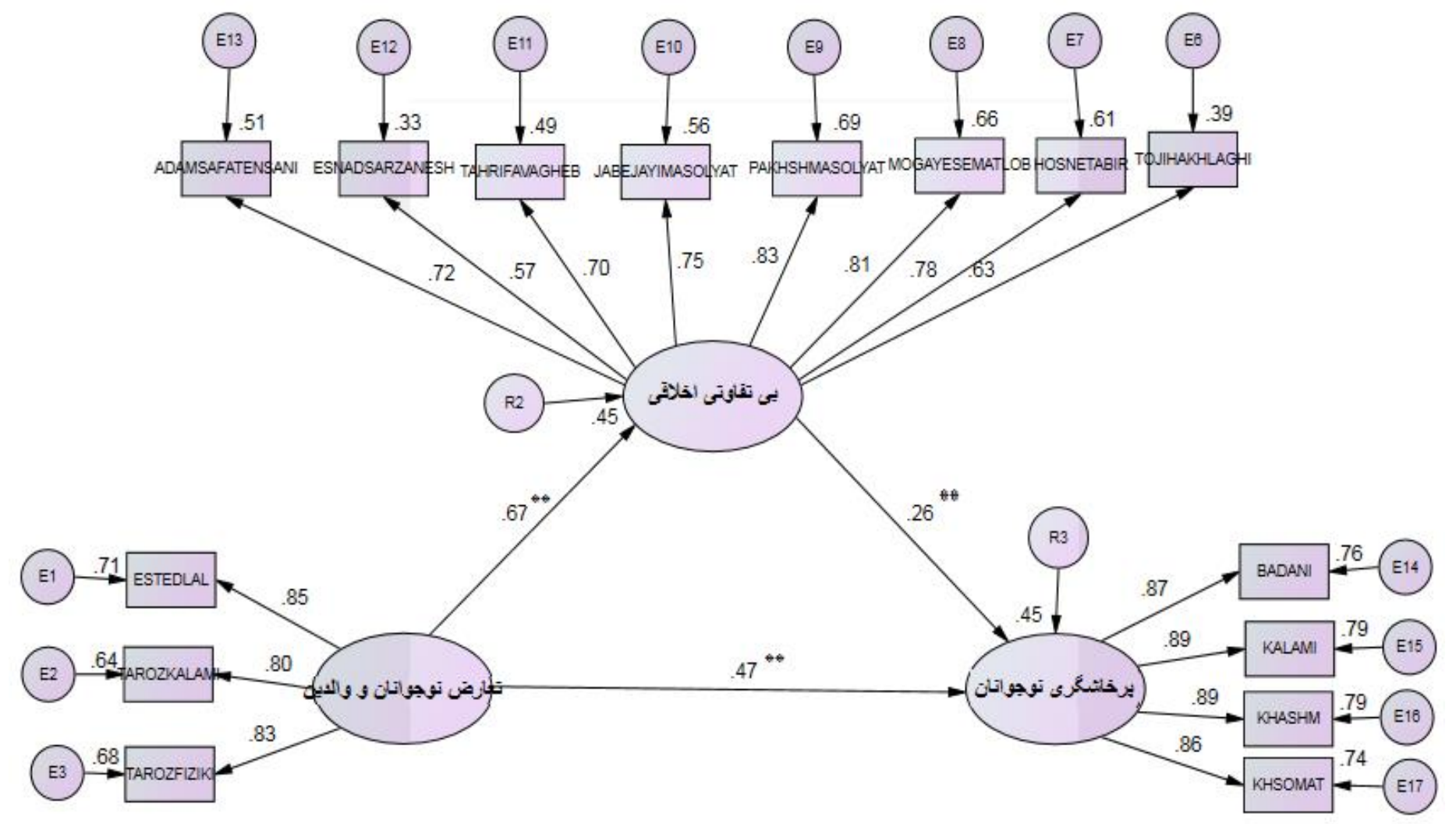

شكل r: الكوى آزمون شده يُوهش

F اثرات مستقيم، آماره تى، و سطح معنادارى متغيرهاى يُزوهش گزارش

شده است.
با توجه به شـكل rا، تعارض نوجوانان و والدين و بـىتفاوتى اخلاقى،

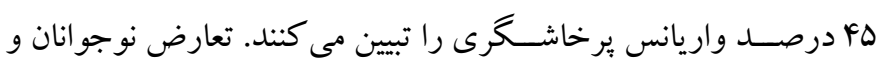

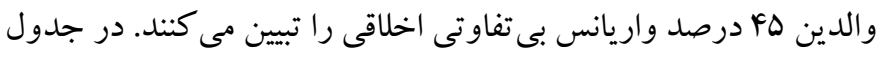

جدول ع: نتايج مربوط به اثرات مستقيم

\begin{tabular}{|c|c|c|c|c|c|}
\hline سطح معنادارى & to Toار & خطاى استاندارد بر آورد & ضريب مسير & برآورد يارامتر & مسير ها \\
\hline & & & & & به روى يرخاشگرى نوجو انان از: \\
\hline.$\cdot \cdot 1$ & $4 / 999$ & $\cdot / 79$ & $\cdot / \varphi^{* * * *}$ & $\cdot / 49$ & بع تفاوتى اخلاقى \\
\hline \multirow[t]{2}{*}{.$/ \cdot 1$} & $\wedge / \Delta \wedge 9$ & $\cdot / r \mid$ & $\cdot / \mathcal{A} V^{* * *}$ & .194 & تعارض نوجوانان و والدين \\
\hline & & & & & به روى بى تفاوتى اخلاقى از: \\
\hline$\%$ & $1 r / 901$ & $\cdot / 1 \wedge$ & $\cdot 19 \mathrm{~V}^{\text {*** }}$ & $\cdot / \mathrm{VA}$ & تعارض نوجوانان و والدين \\
\hline
\end{tabular}


با توجه به ضـريب مســير (19V•) و همجينين آماره t به مقدار (1/901) مى توان كفت در سطح اطمينان 99 درصد، تعارض نوجوانان و والدين بر بى تفاوتى اخلاقى تأثير مثبت و معنادارى دارد. يكى ديخر از ويز گى هـاى معـادلـات ســـاختـارى بررســى اثرات غير مستقيم متغيرها بر يكديخر است. در جدول ه نتايج اثرات غيرمستقيم ارائه شده است.
همان طور كه در جدول F مشـاهده مى شود با توجه به ضريب مسير

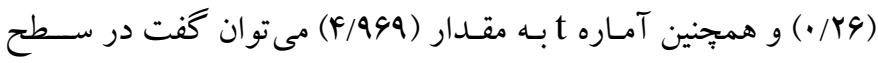
اطمينان 99 درصد، بى تفاوتى اخلاقى بر برخاشخرى نوجوانان تأثير مثبت

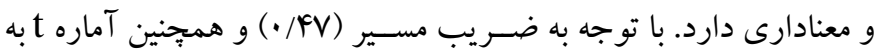
مقـدار ( نوجوانان و والدين بر يرخاشـكرى نوجوانان تأثير مثبت و معنادارى دارد.

\section{جدول 0: نتايج مربوط به اثر غيرمستقيم تعارض نوجوانان و والدين بر يرخاشكرى نوجوانان از طريق بى تفاوتى اخلاقى}

\begin{tabular}{|c|c|c|c|c|c|}
\hline سطح معنادارى & t & خطاى استاندارد بر آورد & ضريب مسير & بر آورد يارامتر & 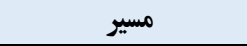 \\
\hline.$\cdot \cdot 1$ & $f / 999$ & $\cdot / \cdot 1$ & $\cdot / I V^{* * n}$ & $\cdot|4|$ & تعارض نوجوانان و والدين \\
\hline
\end{tabular}

والدين با فرزندان، مهم ترين عنصـر شـكلدهنده اين سـازمان است. رشد مطلوب و ســالم فرزنـدان در تمـام ابعـاد، مرهون ارتباط مؤثر و مطلوب والدين با فرزندان اســت. تحليل هاى نظرى و تجربى بســيارى به ارتباط كار آمد والدين با فرزندان اختصـاص دارد كه براى آن اهميت و ارزشى خاص قائل شدهاند. از سوى ديخر مطالعات فراوانى به تأثير كيفيت رابطه والد - فرزندى بر هر يكك از اعضاى خانو اده به عنوان يكك رابطه دو جانبه توجه داشـتهاند. بديهى اسـت زندكى از دوران بلوغ آغاز نمى شود، بلكه در طى سـالهـاى كودكى شـكـل مى گيرد و كود كى فرا مى كيرد كـه.

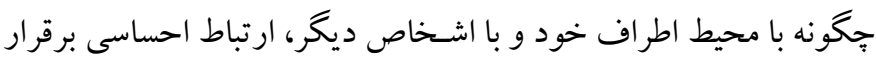
كند. كود كانى، خوشـبخت هسـتند كه در خانو ادههاى باثبات به سـر مى برند و ارتباط نزديكى بين والدين و آنان وجود دارد. در خانو ادههايى كه آرامش و ثبات برقرار اسـت، روابط نزديكك والد- فرزندى وجود دارد و والدين با فرصـتهاى بى شــمارى كه براى فرزندان خود فراهم مى كنند، زمينه لازم را براى زندكى موفقيت آميز فرزندان تداركك مىبيند. از سوى ديخر، سبك تربيتى ناسالم خانو اده و كار كرد معيوب خانواده باعث بروز اختلالات رفتارى، بزهكارى و يرخاشــرى در فرزندان مىشــود. بر اين اسـاس مى توان استنباط كرد كه خانو اده به عنوان مهممترين نهاد اجتماعى جـامعـه، تـأثير مهمى در نوع نخرش فرزنـدان بـه رفتـارهـاى برخطر و يرخاشخرى دارد. هنگامى كه خانو اده به خوبى كار كند، موجب مىشود كه اعضاى خانواده با احتمال كمترى دجار مشكلات روانشناختى شوند، عملكردهاى منسـجم ترى داشـته باشــد، قادر به انطباق با عو امل تنشـكر
همان طور كه در جدول ه مشـاهده مى شود، با توجه به ضريب مسير

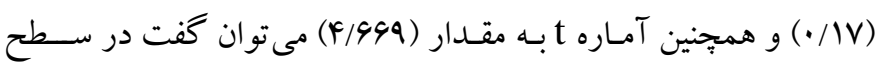
اطمينان 99 درصــد، بى تفاوتى اخلاقى در ارتباط بين تعارض نوجوانان و والدين و يرخاشخرى نوجوانان، نقش ميانجى مثبت و معنادارى دارد.

\section{بحث و نتيجه كيرى} هـدف يثزوهش حاضــر مدل يابى روابط ســاختارى تعارض نوجوانان و والـدين بــا يرخـاشـــرى از طريق نقش ميـانجى بـى تفـاوتى اخلـاقى در نوجوانان دختر با اسـتفاده از روش معادلات ساختارى بود. نتايج معادلات سـاختارى نشـان داد كه الكوى بيشنهادى با دادههاى اين بزّوهش برازش نسـبتاً خوبى دارد و مى تواند ه\& درصـد واريانس برخاشگرى نوجوانان و ها درصد واريانس بى تفاوتى اخلاقى را تبيين كند. نتـايج معادلات ســاختارى نشــان داد تعارض نوجوانان و والدين بر

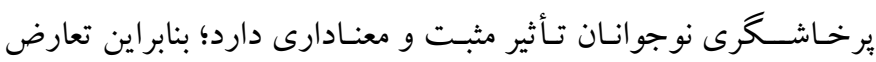
نوجوانـان و والدين به افزايش برخاشــرى نوجوانان منجر مى شــود. با

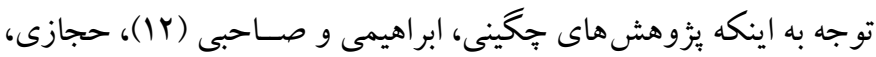
بـاباخانى و احمدى (سا)، يورمند، محســنزاده و قائدنياى (IF)، كارثه، سـوليوان و كورمان-اسـميت ( •(1) و لابلا و ماسـتن (11) نشـان دادند كه تعارض نوجوانان و والدين منجر به افزايش برخاشخرى مىشود، بنابراين منطقى اســت كه بين تعارض نوجوانان و والدين و برخاشـــرى، رابطه وجود داشـتـه بـاشــد. در تبين اين يافته مى توان كفت كه خانواده يكك سـازمان اجتماعى كو جّك اسـت كه روابط اعضـاى آن به ويزّه روابط 
نتسايج اين مطالعه نشــان داد كه تعارض نوجوانان و والدين از طريق

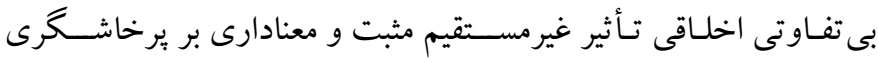

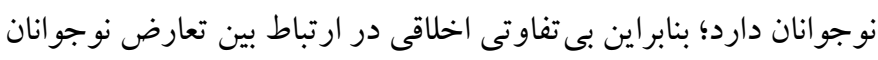

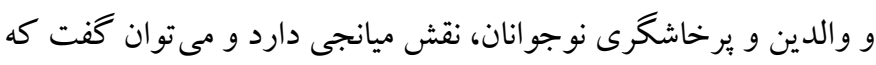

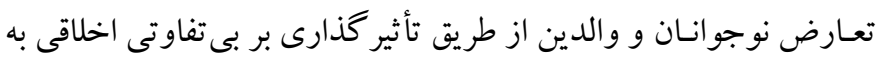

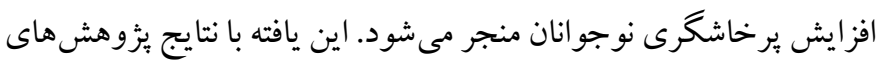

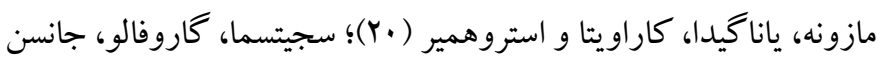

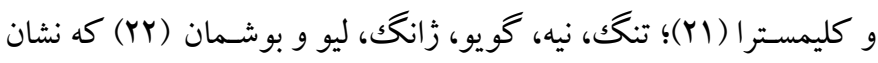

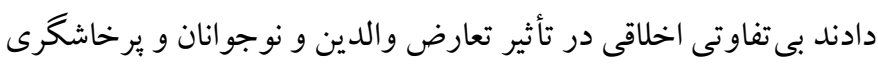

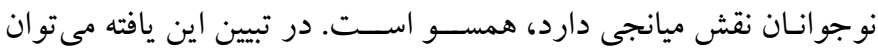

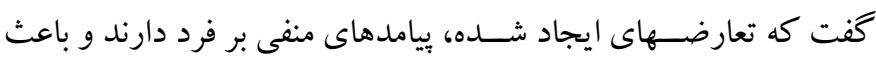

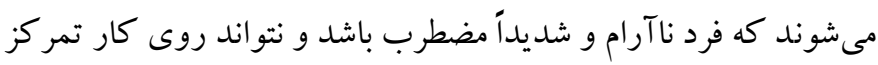

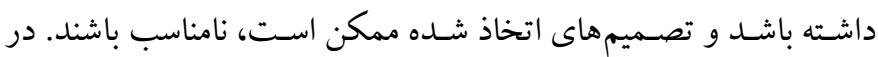

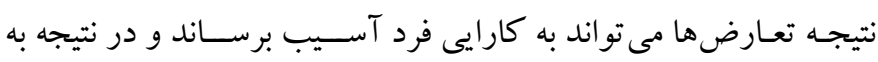
كاهش بى تفاوتى اخلاقى و افزايش برخاشكرى، منجر شوند.

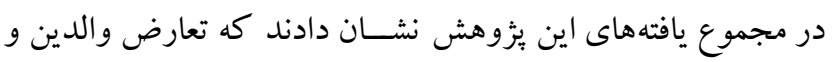

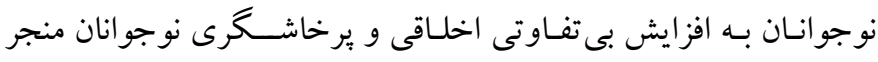

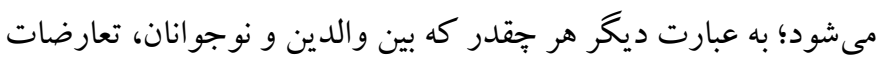

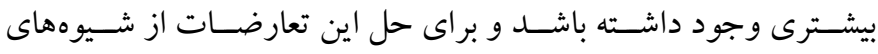

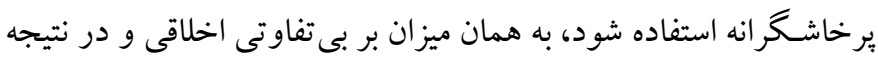

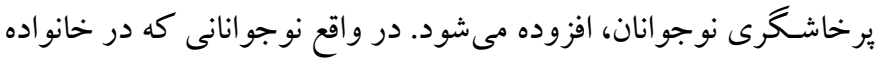
آنان براى حل تعارضات از شيوههاى يرخاشخر انه استفاده مى شوده، آنان

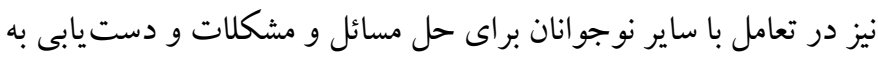

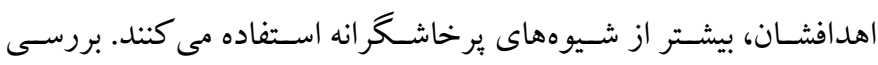
مطالعات انجام شـده نشـان داد كه تاكنون بزوهشسى به بررسى تعارضات

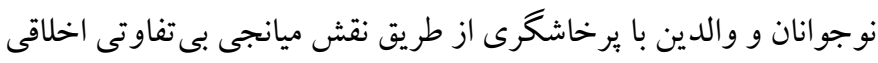

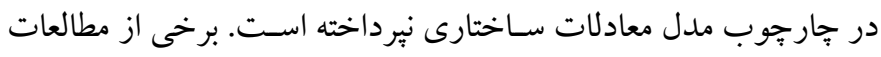

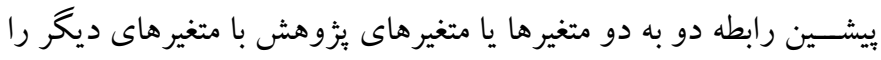

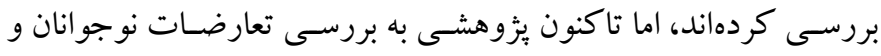

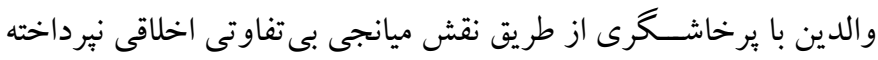

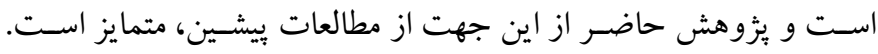

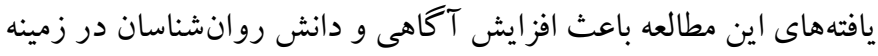

باشـند، قو اعد و مرزهاى خانو ادگى مشـخص و آشكارى داشته باشند، و در نتيجه تمايل كمترى به برخاشخرى داشته باشند.

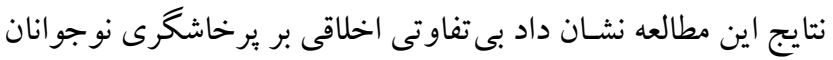

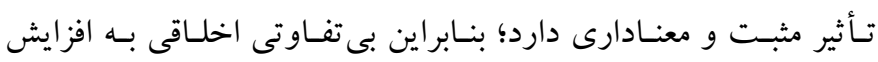

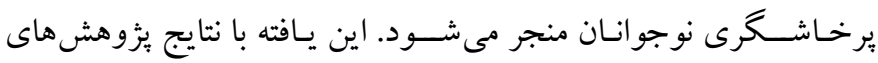

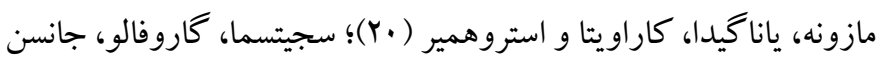

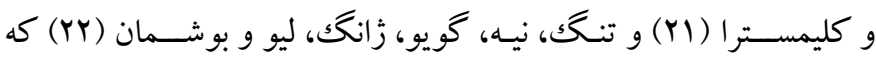

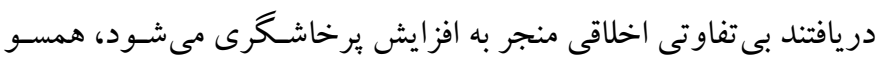

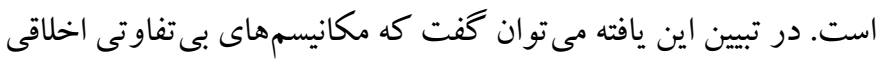

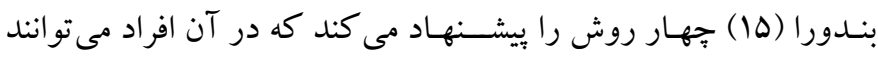
رفتارهاى خود را كه از نظر اخلاقى اشتباه هستند، توجيه كنند. اين جهار

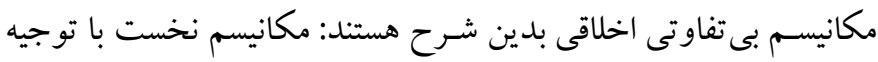

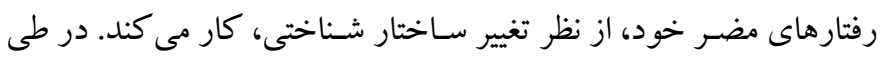

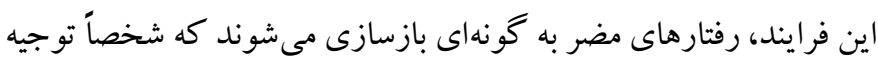

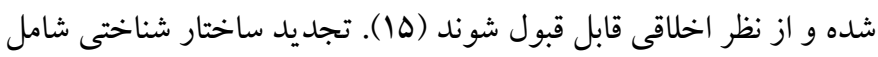

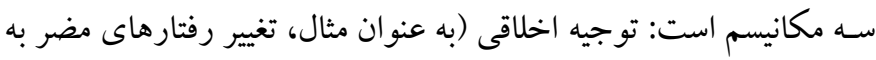

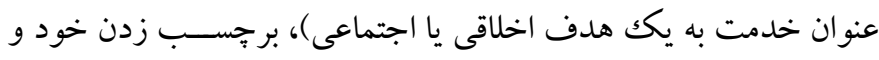

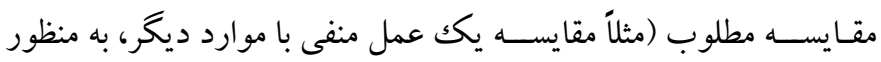

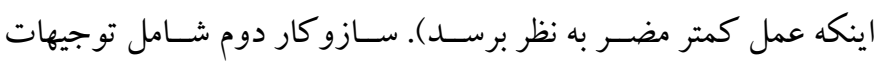

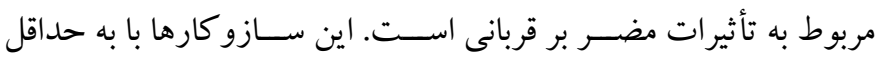

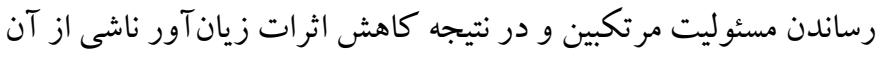
كار مى كنند. مكانيســم ســوم شــامل بيوندى بين رفتار آنها و تأثيرات

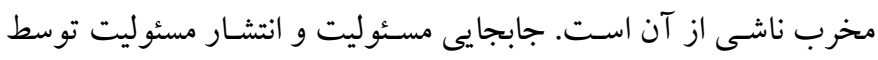
مجرمان توجيه مى شـود كه كمتر مسـئول رفتارهاى غير اخلاقى هسـتند. سر انجام، سازو كارهايى كه باعث از دست رفتن هويت شخصى مربوط به به قربانى مى شـوند، مانند از دسـت دادن صفات انسانى و انتساب سرزنش،

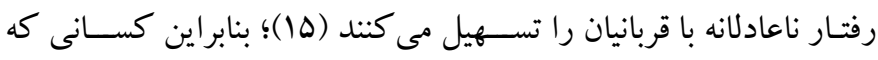

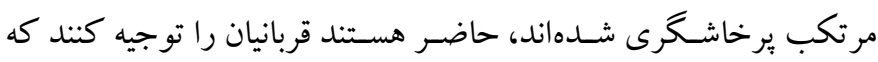

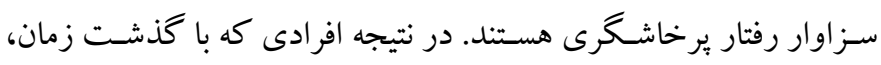

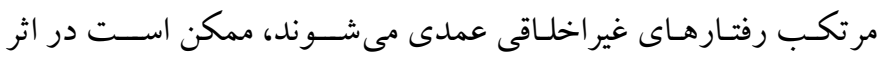
آسيبديدگى يكك قربانى احساس گناه نكنند، و حتى از طريق توجيهات شناختى رفتار خود را مناسب بداند. 
بيشــنهاد مىشـــود در يزوهش هاى آينده از روشهاى يزوهش كيفى و آميخته براى شناسايى عوامل مؤثر بر برخاشكرى نوجوانان، استفاده شود.

IR.IAU.BABOL. تشــكر و قــرودانى: اين بثروهش بـا كـــ اخلـاق REC.1399.013 بر گرفته از رسـاله دكتراى خانم زهره محمدعينى در رشته

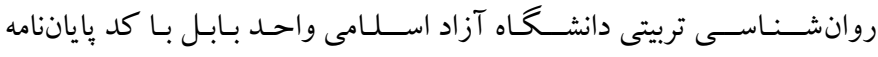

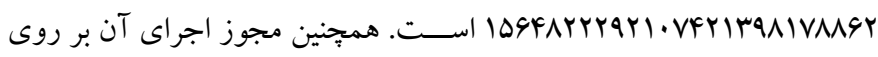

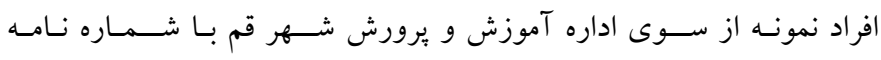
. مســولان اداره آموزش و برورش مخصــوصـاً كارشـناس هســه مشــاوره كه هماهنگ با مدارس جهت آموزش و يزٔوهش را انجام دادند و همجينين از كادر ادارى و مربيان مدارس و افراد نمونه كه در اجراى اين طرح به ما كمكك كردند، تشكر و قدردانى مى شود.

تضــاد منافع: نويســدكان اين مقاله، هيج گونه تضــاد منافعى رادر گزارش يافته هاى اين بثزوهش، گزارش نكردهاند.
علل زيربنايى برخاشخرى نوجوانان شده و در كنار يافته هاى بيشين، زمينه را براى تـدوين نظريـه در حوزه الكوهاى تعاملى و تعارضــات والدين و نوجوانان و تأثير آنها بر بى تفاوتى اخلاقى و يرخاشـكرى نوجو انان فراهم مى كند.

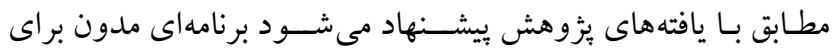
آموزش مهـارتهـاى ارتبـاطى بين نوجوانـان و والـدين بـه صـورت كار كاههاى آموزشى و همجنين تدوين كتابجهه هاى كاربردى متعددى در اين زمينه براى دانش آموزان در نظر كرفته شود. برنامهريزى و اجر ایى هر برنامه مربوط به كاهش بـى تفاوتى اخلاقى، مســتلزم تشــخيص عناصـر و مؤلفـهـــاى مؤثر در آن اســـ؛ بنـابراين، نتايج حاصـل از اين بئوهش مى تواند مورد توجه برنامهريزىها، اقدامات، و اصلاحات نهادهاى رسمى تورى قرار كيرد. در اين مطـالعـه تنهـا نمونسهاى از دانش آموزان دختر مقطع متوسطه در شهر قم بررسى شد؛ بنابر اين تعميم يافته به ديخر دانش آموزان و مقـاطع ســنى و همجنين نوجوانـان يســـر با محدوديت مواجه اســت. همجينين، يافتها بر اسـاس دادههاى خود گز ارشدهى هسـتند و در نتيجه 


\section{References}

1. Malti T, Rubin KH. Handbook of child and adolescent aggression. Guilford Publications; 2018, pp: 22-35. [Link]

2. Elam KK, Chassin L, Pandika D. Polygenic risk, family cohesion, and adolescent aggression in Mexican American and European American families: Developmental pathways to alcohol use. Dev Psychopathol. 2018; 30(5): 1715-1728. [Link]

3. Sukhodolsky DG, Wyk BCV, Eilbott JA, McCauley SA, Ibrahim K, Crowley MJ, et al. Neural mechanisms of cognitive-behavioral therapy for aggression in children and adolescents: Design of a randomized controlled trial within the national institute for mental health research domain criteria construct of frustrative non-reward. J Child Adolesc Psychopharmacol. 2016; 26(1): 38-48. [Link]

4. Koroshi Moghadam T, Esfahani Asl M. Evaluation and expression of the effectiveness of anger management skills on students' aggression. The first national conference on heart and sports. 2018. [Persian]. [Link]

5. Dortaj F, Masaebi A, Asadzadeh H. The effect of anger management on aggression and social adjustment of 12-15 years old male students. Journal of Applied Psychology. 2010; 3(4): 62-72. [Persian]. [Link]

6. Beyens I, Beullens K. Parent-child conflict about children's tablet use: The role of parental mediation. New Media Soc. 2017; 19(12): 2075-93. [Link]

7. Delgado MY, Nair RL, Updegraff KA, Umaña-Taylor AJ. Discrimination, parent-adolescent conflict, and peer intimacy: examining risk and resilience in Mexican-origin youths' adjustment trajectories. Child Dev. 2019; 90(3):894-910. [Link]

8. Holmbeck GN. A model of family relational transformations during the transition to adolescence: Parent-adolescent conflict and adaptation.2018. [Link]

9. Thomas SA, Jain A, Wilson T, Deros DE, Jacobs I, Dunn EJ, Aldao A, Stadnik R, De Los Reyes A. Moderated mediation of the link between parentadolescent conflict and adolescent risk-taking: The role of physiological regulation and hostile behavior in an experimentally controlled investigation. J Psychopathol Behav Assess. 2019; 41(4):699-715. [Link]

10. Garthe RC, Sullivan TN, Gorman-Smith D. The family context and adolescent dating violence: a latent class analysis of family relationships and parenting behaviors. J Youth Adolesc. 2019; 48(7):1418-32. [Link]

11. Labella MH, Masten AS. Family influences on the development of aggression and violence. Curr Opin Psychol. 2018; 19:11-6. [Link]

12. Chegini L, Ebrahimi M.I, Sahebi A. The effect of teaching choice theory to parents on the aggression of their students' children in primary school. Child Ment Health.2019; 6 (1): 70-82. [Persian]. [Link]

13. Hejazi E, Babakhani N, Sadat Ahmadi S.N. The effectiveness of interpersonal communication skills training on aggression and impulsive behaviors among high school students. J Res Edu Sys. 2018; 12 (40): 25-38. [Persian]. [Link]

14. Pourmand F, Mohsenzadeh F, Qahednia Jahromi A. The relationship between family functioning, domestic violence and parent-child relationship with the behavior of victims of bullying among high school girls. Soc Health. 2017; 4 (4): 275-285. [Persian]. [Link]

15. Bandura A. Social foundations of thought and action. Englewood Cliffs, NJ. 1986; 1986:23-8.

16. Bandura A. Selective activation and disengagement of moral control. J Soc Issues. 1990; 46(1):27-46. [Link]

17. Bandura A. Moral disengagement: How people do harm and live with themselves. Worth Publishers; 2016. [Link]

18. Bandura A. Selective moral disengagement in the exercise of moral agency. J Moral Educ. 2002; 31(2):101-19. [Link]

19. Gini G, Thornberg R, Pozzoli T. Individual moral disengagement and bystander behavior in bullying: The role of moral distress and collective moral disengagement. Psychol Violence. 2018. [Link]

20. Mazzone A, Yanagida T, CS Caravita S, Strohmeier D. Moral emotions and moral disengagement: Concurrent and longitudinal associations with aggressive behavior among early adolescents. J Early Adolesc. 2019;39(6):839-63.[Link]

21. Sijtsema JJ, Garofalo C, Jansen K, Klimstra TA. Disengaging from evil: Longitudinal associations between the dark triad, moral disengagement, and antisocial behavior in adolescence. $\mathrm{J}$ Abnorm Child Psychol. 2019; 47(8):1351-65. [Link]

22. Teng Z, Nie Q, Guo C, Zhang Q, Liu Y, Bushman BJ. A longitudinal study of link between exposure to violent video games and aggression in Chinese adolescents: The mediating role of moral disengagement. Dev Psychol. 2019;55(1):184.[Link] 
23. Ghasemi, V. Optimal sample size estimation in structural equation models and its adequacy assessment for social researchers. Iran Sociol. 2011; 12(4): 138-161. [Persian]. [Link]

24. Buss AH, Perry M. The aggression questionnaire. J Pers Soc Psychol. 1992; 63(3):452. [Link]

25. Mohammadi, N. Preliminary study of psychometric indices of Bass-Perry aggression questionnaire. 2006. [Link]

26. Fine, M. A., Moreland, J. R., \& Schwebel, A. I. Longterm effects of divorce on parent-child relationships. Dev Psychol, 1983; 19(5), 703. [Link]
27. Zaboli, P. Assessing the usefulness of psychoanalytic method in improving conflict resolution skills of girls with mothers of first year high school students in Tehran Region 2. Master Thesis, Khatam University; 2004. [Persian]. [Link]

28. Caprara GV, Capanna C. Moral disengagement in the exercise of civic-ness. Interdisciplinary Yearbook of Business Ethics. 2006; 1(2006):87-98. [Link] 